\title{
Teaching the Effect of Limestone Particle Fixation on Batik Natural Color Density in Inclusive Classroom
}

\author{
Dinar Westri Andini ${ }^{1,2}$, Asep Bayu Dani Nandiyanto ${ }^{1^{*}}$, Achmad Hufad ${ }^{1 * *}$, Ayu Fitri Amalia ${ }^{2}$ \\ ${ }^{1}$ Universitas Pendidikan Indonesia, J1. Dr. Setiabudi No. 229 Bandung, Indonesia \\ ${ }^{2}$ Universitas Sarjanawiyata Tamansiswa, J1. Batikan, Tuntungan UH III, DI. Yogyakarta, Indonesia \\ 1'dinarwestriandini@upi.edu,nandiyanto@upi.edu, achmadhufad@upi.edu \\ 2dinar@ustjogja.ac.id, ayufitriamalia@ustjogja.ac.id
}

\begin{abstract}
The purpose of this study is to teach how the effect amount of limestone particles on batik color density on students in inclusive-setting classrooms. Experiments are carried out on two groups of students. Nine students from vocational school and five students from secondary high school from the science program. The research used singlesubject research with multiple baseline designs between research subjects by comparing two groups in understanding the content through applying in functional activities by giving the same activities starting with a pretest, giving material, and posttest. The experimental procedure is started by sifting the limestone with coconut milk and tea sieve and soaking the lime solution for one night. Then, taking the solution and mixed it with turmeric powder. In obtaining other color variations, the sample is diluted into water to get 1:1 ratio. The experimental results show that the finer the lime particles, the darker the color and the stronger the lime concentration produce. It shows that the concentration of the solution greatly affects the color density. This learning method is capable of cultivating the curiosity of all students including students with special needs. However, for students with double disabilities, they require direct practice and concise guidance.
\end{abstract}

Keywords: Batik, Color Density, Fixation, Inclusive, Limestone Particles

\section{Corresponding Author}

*Universitas Pendidikan Indonesia, Jl. Dr. Setiabudi

No. 229 Bandung, Indonesia

*nandiyanto@upi.edu

** Universitas Pendidikan Indonesia, J1. Dr. Setiabudi

No. 229 Bandung, Indonesia

**achmadhufad@upi.edu

\section{Introduction}

Educating students on how to make natural colors in batik is essential to improve students' knowledge to develop eco-friendly fabric coloring techniques (Oktiani, Ragadhita, Nandiyanto, Widiaty, 2020; Oktiani, Ragadhita, Nandiyanto, Sukmafitri, Shintabella, and Widiaty, 2019). Batik is very important since it is one of the heritages of Indonesia (Widiaty, Riza, Abdullah, and Mubaroq, 2020).

Recently, several techniques have been developed to foster eco-fashion (Handayani, Kristijanto, and Hunga, 2018; Wirawan and Alvin, 2019). As known, natural color contributes a positive impact on the environment (Pujilestari, 2015; Suheryanto and Haryanto, 2008) and the materials are accessible as it is easy to find. Besides, natural colors are relatively cheap (Amalia and Akhtamimi, 2016; Handayani, Kristijanto, and Hunga, 2018; Setyawati, Darmokoesoemo, Ningtyas, Kadmi, Elmsellem and Kusuma, 2017). However, sometimes there are still many misconceptions of people who claim that natural colors do not provide economic benefits due to their long processing time, and limited color diversity (Hakiim, Sari and Efelina, 2019).

Several studies have been conducted to develop natural color absorption so the colors last longer. Thi study is conducted by extracting five natural ingredients using water and using lime fixation, gazebo, alum, lime mixture with drops and without fixation. The natural ingredients are used to determine the effect of adding water to the extraction and fixing agent on the colorfastness of the fabric (Oktiani, Ragadhita, Nandiyanto, Widiaty, 2020; Oktiani, Ragadhita, Nandiyanto, Sukmafitri, Shintabella, and Widiaty, 2019). The research results show that the extraction of natural dyes by adding 6 to 8 parts of water do not produce many different results, and the fixation applied to provide good clothes fastness (Pujilestari, 2014). Another case found in research conducted by Oktiani, Ragadhita, Nandiyanto, and Widiaty (2020), which found that the fixing agent used could produce different fabric colors due to differences in the tannin metal 
ion complexes. The fixing agents used are iron sulfate, lime, and alum. Also, differences in solvents in the extraction of natural materials used have different effects on color sharpness.

The results of other studies also state that soaking cloth at a concentration of $100 \mathrm{~g} / \mathrm{L}$ of alum with a five minutes fixation time results in colorfastness and optimal color (Pumaningtyas, 2014). Likewise, some researchers stated that the use of concentration has a value category. It is not much different for color resistance but has better quality in the fixation/non-fixation treatment with aerobic fermentation (Hakim, Sari, and Efelina, 2019). Another study treated the natural colors by mixing and heating salt at a certain temperature and then soaking the cloth in the liquid overnight (Mayusoh, 2015). However, until now research to teach the effect of the concentration of whiting particles on the natural colors' density of batik in diverse classes also known as inclusive classes are limited. An inclusive class is a class in which there is a diversity of students including diversity of abilities, gender, social and cultural background (Moriña, 2017)

Based on the research that has been conducted, most researchers have used various fixing agents to generate colors. Whereas in this study, this research aims to teach and find various colors based on the limestone particle fixation substance used and the dilution of different solutions by adding water. Through these brief stages, can explore natural colors using materials that are easy to obtain and simple in the manufacturing process. The results show that the finer the particles of limestone with a saturated concentration (ppm), the denser the color. This proves that the concentration of the solution will affect the color density, the higher the concentration of the solution, the stronger the color will bind. In making color gradations, the student could dilute the solution by mixing the concentration of the solution with water-based on a ratio 1:1.

\section{Theoretical Framework}

\subsection{Solution and concentration}

A solution is a homogeneous mixture of two or more substances (Suparwati, 2017). The substances that have a large amount in a solution are called solvents, while those that have the smallest amount compared to other substances are called dissolved or solute. Inside the solution, there is a solution concentration. The solution concentration is a quantity that shows the concentration of a solution, which has a ratio between the solvent and the solute. If the solute in a solution is high, the concentration of the solution has a high or high-density concentration, and vice versa, if the solute is low, then the concentration is low (dilute).

In the process of dyeing fabrics, this solution is critical because it becomes a process in dyeing and giving color to the fabric. The increase in dye concentration will increase the amount of color absorption in the fabric (Dewy and Novrita, 2019).

\subsection{Fixation of substances $\mathrm{CaCo3}$}

Fixation is a process of binding or strengthening the color so it has resistance to the fading effect (Kartikasari and Susiati, 2016; Pujilestari, 2014). The purpose of adding a fixation agent is to increase the absorption of the fabric against natural dyes. There are two fixation substances, namely chemical and natural (Purnaningtyas and Sriyanto, 2014). $\mathrm{CaCO}_{3}$ or calcium carbonate is a fixator substance derived from nature. Calcium carbonate usually emerges from the solid lime suspension in water and carbon dioxide gas (Cahyono, Jonas, Lalenoh, and Kota, 2019). In the use of a lime fixator $\left(\mathrm{CaCO}_{3}\right)$, lime $\left(\mathrm{CaCO}_{3}\right)$ would be immersed in water, precipitated, and the clear liquid is taken (Kartikasari and Susiati, 2016).

Figure 2 is the reaction process of water bound by $\mathrm{CaO}$ becomes $\mathrm{Ca}(\mathrm{OH})_{2}$ (Kartikasari and Susiati, 2016). In the figure below, it can be seen that the lime particles in the form of powder would bind more than those in the form of large grains/chunks.

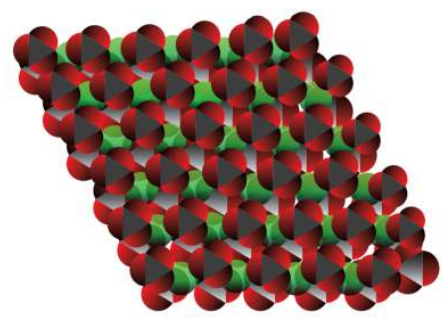

Fig. 1. Calcium Carbonate $\mathrm{CaCO}_{3}$
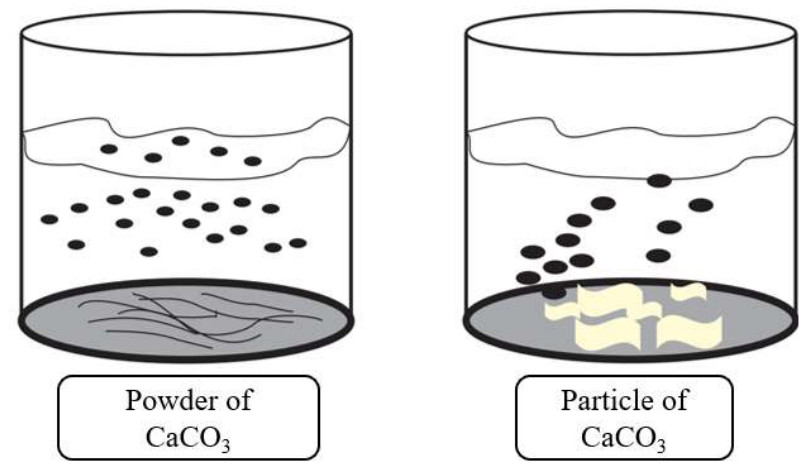

Fig 2. Reaction process of water and $\mathrm{CaO}$

\section{Methods}

\subsection{Materials and Experimental Demonstration Procedure}

The materials used in this experiment use various limestone particle sizes which are sieved using a coconut milk sieve $(2 \mathrm{~mm})$, tea sieve ( 1.6 and $1.2 \mathrm{~mm})$, and unfiltered limestone particles so the grains are irregular. This method to find out how much the absorption and solution concentration of the differences in the limestone's particles size. The limestone particles soak in water for one night, and the clear liquid is taken. Then the solution is mixed with turmeric powder (Desaku, produced by PT. Motasa Indonesia) with water (Aqua; produced by PT Unilever, Indonesia).

Figure 3 shows the steps performed in the experiment, including: 
(1) Preparing limestone and turmeric powder as well as a sieve tool with different diameter sizes $(1.2,1.6$, and $2 \mathrm{~mm})$.

(2) Shifting the limestone powder and reserve based on the particle size, starting from the smoothest.

(3) Roasting each limestone particle to remove the water content.

(4) Weighing the limestone particles (100 g each)

(5) Soaking each limestone particle overnight with $1 \mathrm{~L}$ of water.

(6) Taking clear water from the limestone sediment $(100 \mathrm{~mL}$ each).
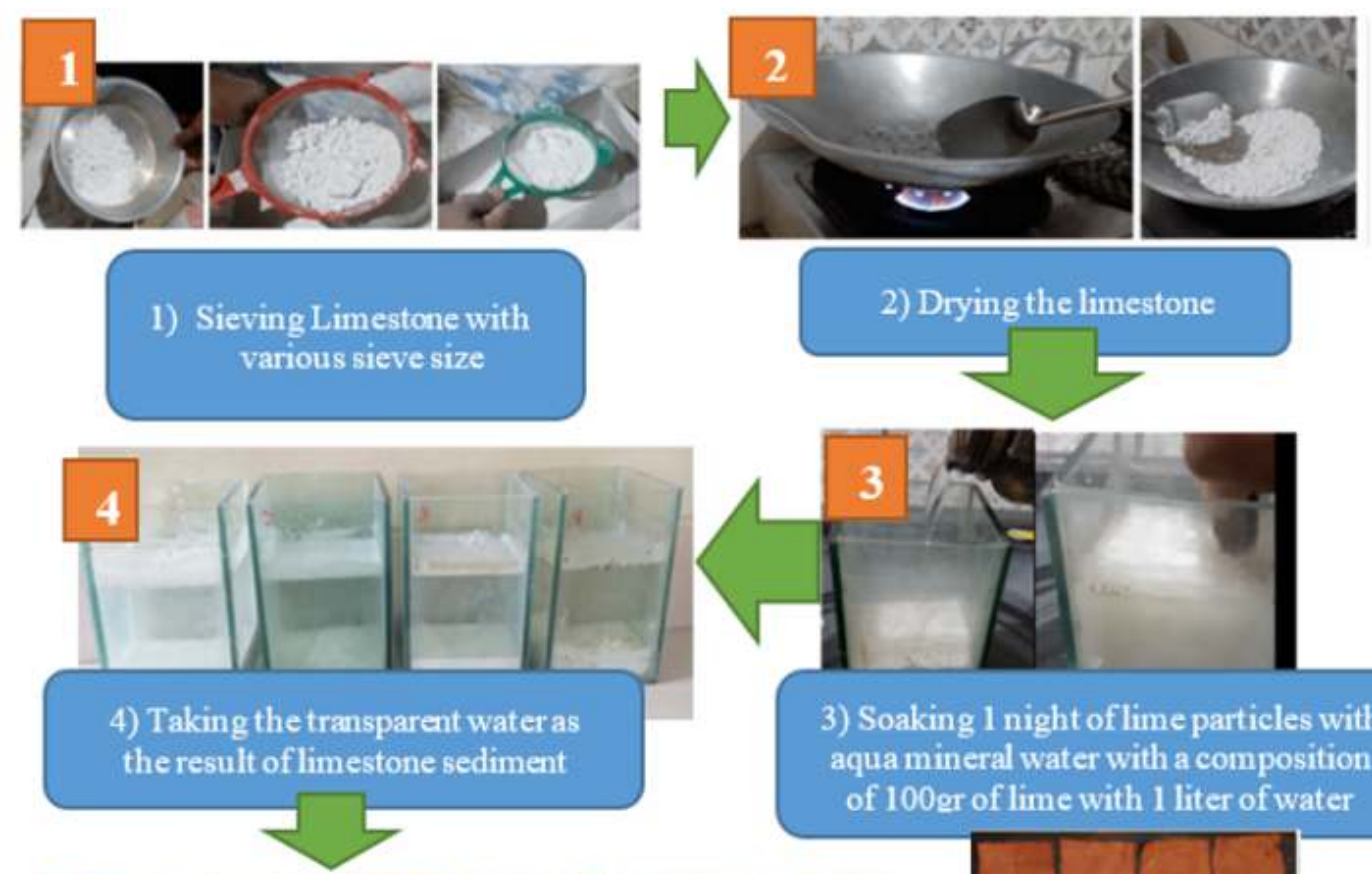

container.

(8) Making color variations by diluting the concentrated solution in a ratio of $1: 1$.

(9) Soaking the cloth in each solution.

(10) Drying the cloth with the same temperature, light and time.

(11) Roasting the limestone sediment and turmeric powder to determine the concentration of the substance.

(12) Measuring the quality of color absorption using the colorimeter application on the Samsung J6 Android phone.

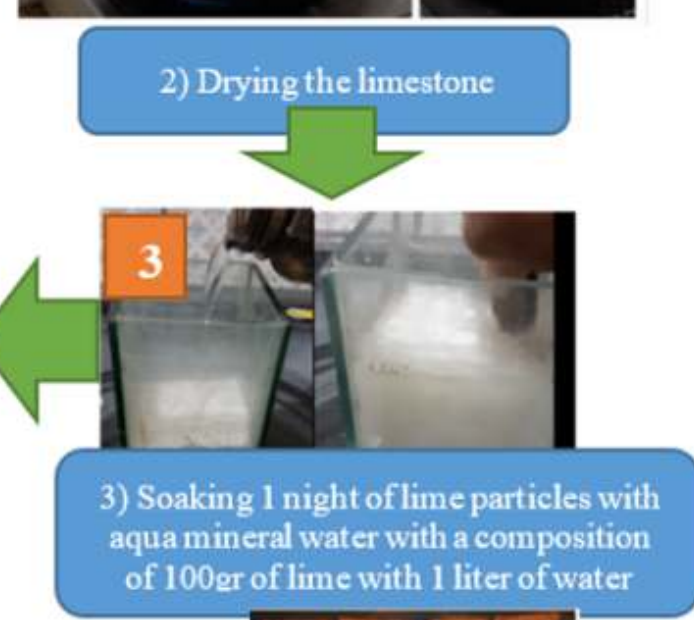

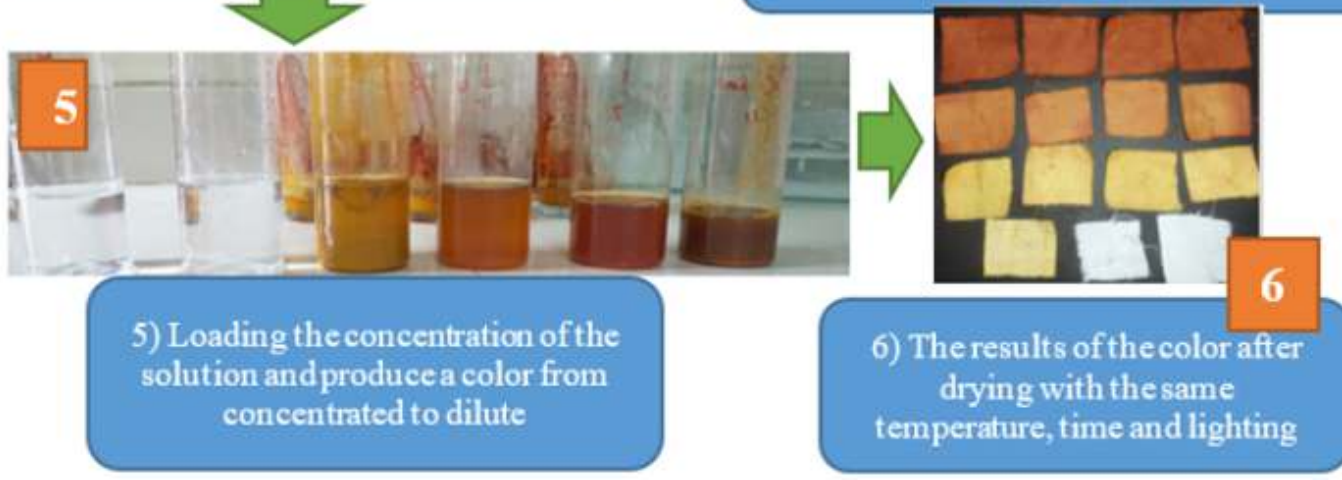

Fig. 3 The experiments steps

\subsection{Research Subject}

The experiments are conducted with two groups of students. Nine students are vocational school students and five students are high school students in the science program. Every class has a limited number of students because there are fewer private schools in Indonesia compared to public schools. Also, private schools' tuitions are usually more expensive than public schools. Besides, the government regulations state that children's enrollment quotas with special needs are only $10 \%$ of the total number of students in the class, therefore, the number of students in the classroom is fewer. The research method used single-subject research with multiple baseline designs between subjects, comparing the two groups in understanding the content of the material through giving the same activity starting with the pretest of knowing student readiness and initial understanding, providing material and posttests as an effort to detect the shifting knowledge related to the material that has been listened to.

The characteristics of students are diverse where two students are categorized as slow learners; one from each school and one student with autism, and one gifted student.

\subsection{Teaching Strategy}

Figure 4 shows the research procedure conducted. The learning process is performed by sending learning videos 
Journal of Engineering Education Transformations, Volume No 34, December, 2020, eISSN 2394-1707 through the WhatsApp group. Firstly, the pretest is given to assess students' initial understanding. After obtaining data from the initial stage, the video is sent. At the beginning of the short video, batik with natural color is shown to attract students' attention. Then, still, on the video, the students are asked how to make natural colors in simple steps to develop students' curiosity. The video continues with an explanation of the materials and tools used and the steps for making them. In the learning video, the concentration of substances from limestone and turmeric powder is also delivered.

The supporting data is also obtained from the interviews conducted with the teacher to know students' understanding, attitudes, interest, responses, and skills in imitating or applying this experiment.

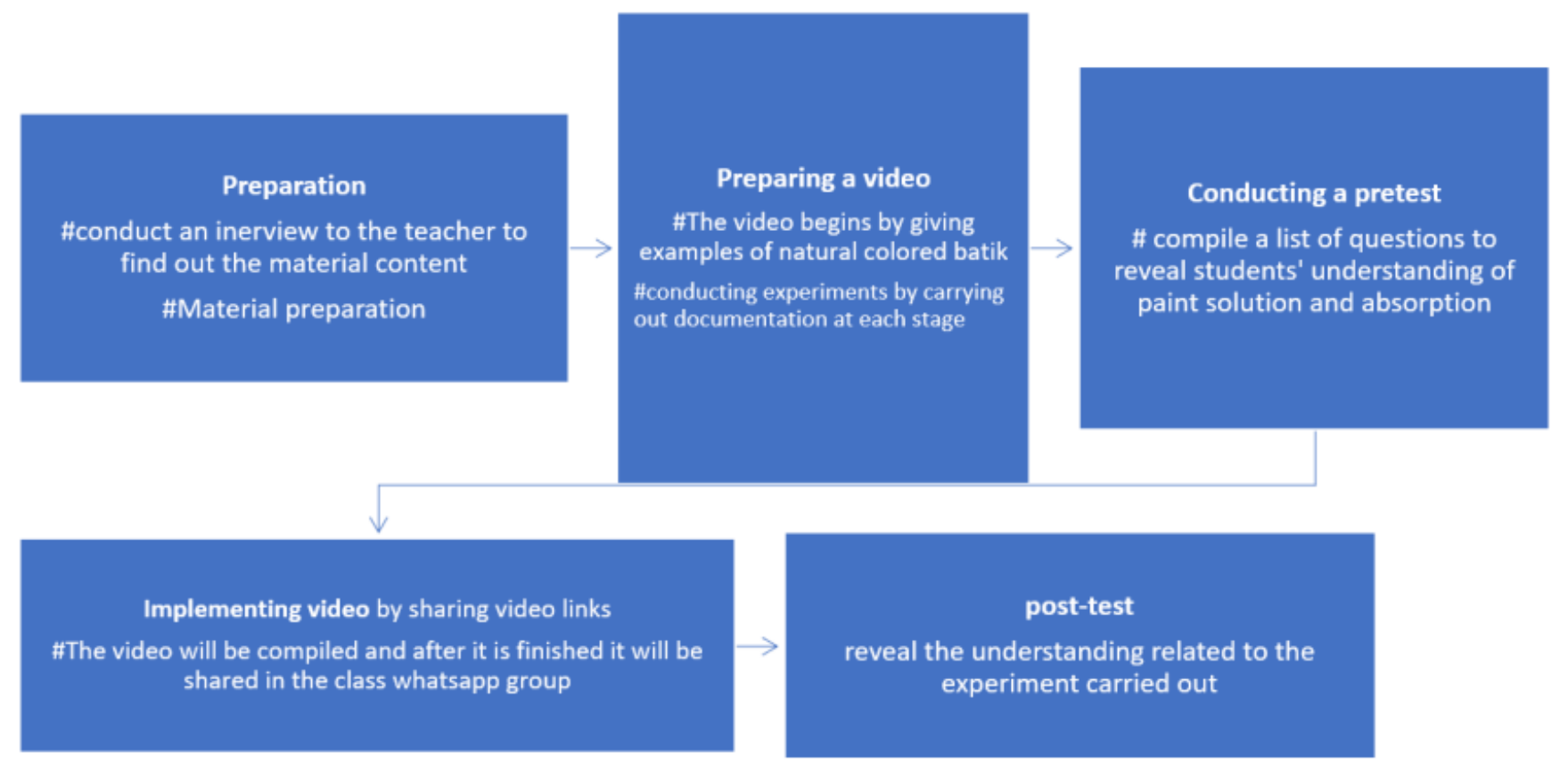

Fig. 4 Research Procedure

\section{Results and Discussions}

\subsection{Experiment Results}

The trial begins by calculating the weight of the lime, which is $100 \mathrm{~g}$ and soaks it in $1 \mathrm{~L}$ of water for one night. Then the results of the lime sediment are taken from the clear liquid that emerges on the top. Table 1 shows the concentration of a soft lime powder, although very little in composition. The volume of water before and after use also changes, almost half of the volume is absorbed by lime.

The clear liquid obtained from the lime deposit is taken $100 \mathrm{~mL}$ each and mixed with turmeric powder weighing 7.5 g. The concentration of the turmeric substance does not change and the weight of the turmeric remains the same at $7.5 \mathrm{~g}$ although it has been used. This is because turmeric has good solubility in water (Munisih, Hartati, and Amroni, 2010). Furthermore, soak the cloth in the solution for five minutes. Then, dry the cloth at the same temperature, light intensity, and time $\left(32^{\circ} \mathrm{C}, 3723\right.$ lux lighting, $\left.30 \mathrm{~min}\right)$.

Figure 5 shows the color result of a concentrated liquid mixture of four clear liquids with different particle sizes from turmeric powder. Based on the color results, it could be seen that the color is almost similar to the color density. However, the fine particles result from a sieve $(1.6 \mathrm{~mm})$, resulting in the darkest color. It proves that the most robust solution concentration will bind more color (Dewy and Novrita, 2019). This result also supported by other studies that state the lime powder absorbs better (Sdiri, Higashi, Jamoussi and Bouaziz, 2012) and natural dyes will be better in color extraction when it is in powder (Radhakrishnan, 2014).

We made color variations by diluting the concentration of the solution through a $1: 1$ ratio. Figure 6 illustrates the color result of the solute dilution with a concentration of $1 / 2$, which means taking $1 / 2$ of the concentrated solution and adding $1 / 2$ water. In this case, $50 \mathrm{~mL}$ of concentrated solution plus $50 \mathrm{~mL}$ of water.

Figure 7 shows the color variations with the concentrated solution dilution ratio of $1 / 10$, meaning taking $10 \mathrm{~mL}$ of high-density solution with the addition of $90 \mathrm{~mL}$ of water.

Table 1. Water volume, limestone weight and substance concentration after immersion

\begin{tabular}{lccc}
\hline $\begin{array}{c}\text { Type of } \\
\text { particle size }\end{array}$ & $\begin{array}{c}\text { Water volume } \\
\text { after } \\
\text { immersion } \\
(\mathbf{m L})\end{array}$ & $\begin{array}{c}\text { Lime } \\
\text { deposit } \\
\text { weight }(\mathbf{g})\end{array}$ & $\begin{array}{c}\text { Lime } \\
\text { concentration } \\
(\mathbf{g} / \mathbf{L})\end{array}$ \\
\hline $\begin{array}{l}\text { Large } \\
\text { irregular } \\
\text { particles } \\
\text { (no sieve) }\end{array}$ & 550 & 100 & 0 \\
\hline $\begin{array}{l}\text { The particles } \\
(2 \mathrm{~mm})\end{array}$ & 500 & 100 & 0 \\
\hline $\begin{array}{l}\text { The particles } \\
(1.2 \mathrm{~mm})\end{array}$ & 500 & 98 & 2 \\
\hline $\begin{array}{l}\text { The particles } \\
(1.6 \mathrm{~mm})\end{array}$ & 550 & 93 & 7 \\
\hline
\end{tabular}




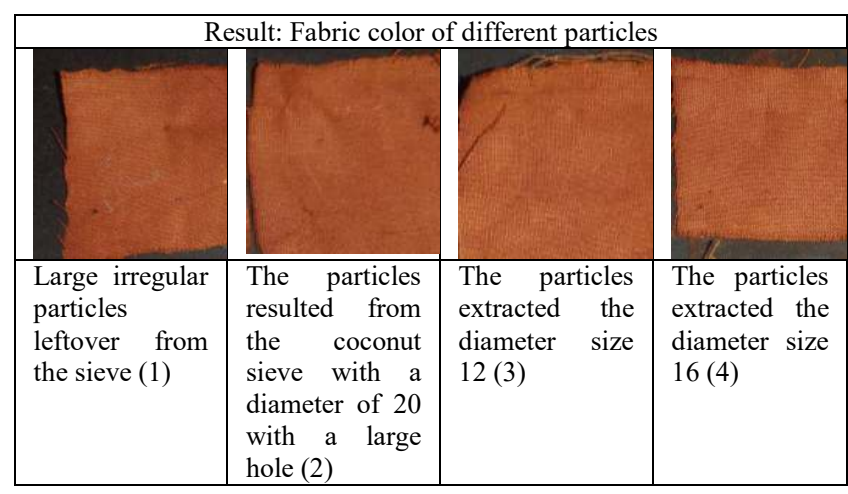

Fig. 5. The color of the concentrated solution

\begin{tabular}{|l|l|l|l|}
\hline \multicolumn{4}{|c|}{ Result: Fabric color of different particles } \\
\hline & & & \\
\hline & & & \\
\hline $\begin{array}{l}\text { Large irregular } \\
\text { particles } \\
\text { leftover from } \\
\text { the sieve (5) }\end{array}$ & $\begin{array}{l}\text { The particles } \\
\text { resulted from the } \\
\text { coconut sieve } \\
\text { with a diameter } \\
\text { of 20 with a large } \\
\text { hole (6) }\end{array}$ & $\begin{array}{l}\text { The particles } \\
\text { diameter the }\end{array}$ & $\begin{array}{l}\text { The particles } \\
\text { extracted the } \\
\text { diameter size } \\
16(8)\end{array}$ \\
\hline
\end{tabular}

Fig. 6 Results from the concentrated solution dilution by ratio $1 / 2$

\begin{tabular}{|l|l|l|l|}
\hline \multicolumn{3}{|c|}{ Result: Fabric color of different particles } \\
\hline & & & \\
\hline
\end{tabular}

Fig. 7 Results from the high-density solution dilution ratio 1/10

Figure 8 displays the color of turmeric dye, limestone solution, and water. The limestone water-soaked fabric has a higher density. It shows that the lime solution is a binder (fixation) (Amalia and Akhtamimi, 2016; Andarsari, 2017), while the cloth that is not soaked in limestone solution, and the color looks faded.

Table 2 displays the calculation of the color measured through the Colorimeter application on the Android J6 cellphone, in a closed room with 119 lux lighting. The types of fabric density with number 4 shows that it has the smoothest particles. It gains the highest red number at 38, so the color looks darker.

Cloth color

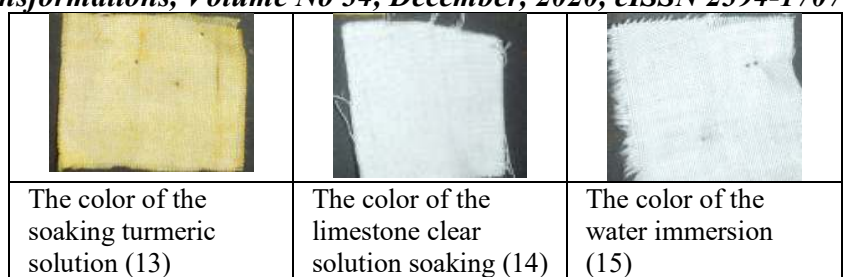

Fig. 8 Color result of turmeric solution, lime solution and water

\subsection{Students' demographic Data}

Fig. 1 shows the initial understanding regarding natural coloring and the composition of how to make natural colors. Vocational high school students understand that in making natural colors, appropriate composition rules are needed. It is related to implementation or application.

\subsection{Phenomena in the learning and teaching process}

There are some students with special needs in both schools. At the vocational school, there is a student with slow learning ability. The student has problems in terms of social interaction and self-confidence, especially when conveying the needs. The student tends to be quiet in class and shy. Meanwhile, one student with special needs who is in high school has autism characteristics and has cognitive barriers. The student has obstacles in communicating as the student communicates in simple language. The student uses English and Indonesian language when communicating as the student once lived abroad. Therefore, the student needs guidance and simple explanations.

During the lesson, students focused on material explanation and watched the video. Parents re-explaining the topic to the students. The student categorizes as the slow learner in vocational high school can understand the material. The student can recall the video, as well as the steps taken to make the experiment. The slow learner student needs to be given an overview of the material with direct practice (Mumpuniarti, Cahyaningrum, 2011). Learning by sending experimental videos is also one of the learning innovations that the teacher has developed. The learning approach used must be able to communicate material while enhancing students' critical thinking skills and also be able to attempt to develop experience-based skills (Ambarwati and Budiningsih, 2018). However, for the student with autism, the student finds it challenging to understand the lesson although the student has watched the video. The student can only answer what the student sees on the video such as water. Other information related to the material still could not be uttered. Therefore, it is necessary to combine various methods so the students can understand the material and the learning. Indeed, it can be accessed by all children (Al-Azawei, Serenelli and Lundqvist, 2016; Mujiono, Dengeng and Praherdhiono, 2018). 
Journal of Engineering Education Transformations, Volume No 34, December, 2020, eISSN 2394-1707 Table 2. Colorimeter measurement results

\begin{tabular}{|c|c|c|c|c|c|}
\hline The type of thickness of the fabric & $\mathbf{R}=\mathbf{R e d}$ & $\mathbf{G}=$ Green & B=Blue & Color Code & Color \\
\hline Density (1) & 36 & 7 & 12 & $\# 24070 \mathrm{C}$ & \\
\hline Density (2) & 37 & 10 & 15 & $\# 250 \mathrm{~A} 0 \mathrm{~F}$ & \\
\hline Density (3) & 37 & 6 & 16 & $\# 250610$ & \\
\hline Density (4) & 38 & 7 & 12 & $\# 26070 \mathrm{C}$ & \\
\hline Ratio 1/2 (5) & 67 & 50 & 69 & $\# 433245$ & \\
\hline Ratio $1 / 2(6)$ & 69 & 56 & 63 & \#45383F & \\
\hline Ratio $1 / 2(7)$ & 85 & 71 & 60 & $\# 55473 \mathrm{C}$ & \\
\hline Ratio $1 / 2(8)$ & 64 & 24 & 33 & $\# 401821$ & \\
\hline Ratio 1/10 (9) & 65 & 46 & 76 & \#412E4C & \\
\hline Ratio 1/10 (10) & 93 & 86 & 70 & \#5D5646 & \\
\hline Ratio 1/10 (11) & 70 & 64 & 78 & \#46404 & \\
\hline Ratio 1/10 (12) & 83 & 68 & 87 & $\# 534457$ & \\
\hline Turmeric solution & 73 & 59 & 58 & \#493B3A & \\
\hline Limestone solution & 141 & 129 & 131 & \#8D8183 & \\
\hline Water & 165 & 167 & 166 & \#B9A7A6 & \\
\hline
\end{tabular}

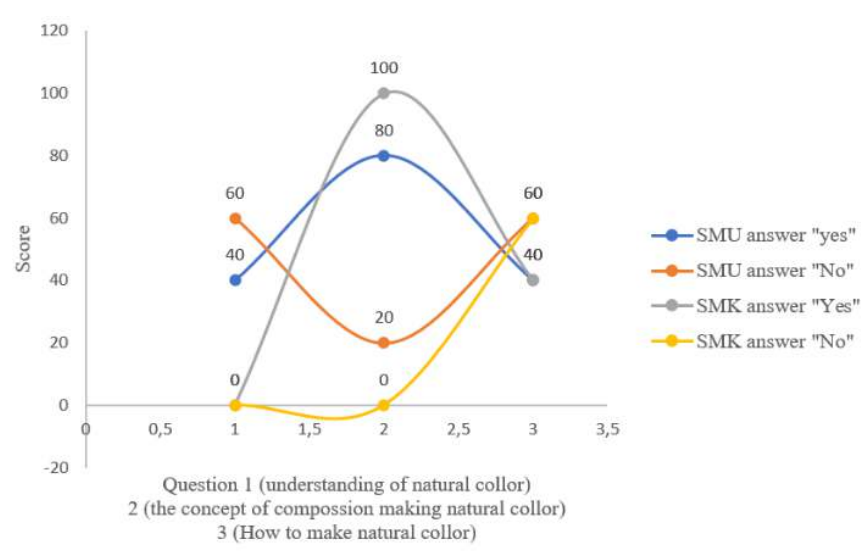

Fig. 1 Understanding the rules for making natural colors. SMU is senior high school, and SMK is a vocational school.
Table 3 shows the results of the pretest and posttest. At the vocational high school and high school levels, the answers related to theory and memorization of the concept, it is found that students from both schools have a good understanding. This demonstration experiment method provides a direct picture and helps students understand the content because it relates to real objects (Ambarwati and Budiningsih, 2018; Budiningsih, 2015; Taylor and Parsons, 2011). However, the application and analysis skills of vocational high school students are exceptional. This supports that vocational school students are more adaptable although it is greatly influenced by environmental support (Prahesty, 2014). While at the high school level, the application and analysis skills will determine the continuation of their education and career. So, it is necessary to conduct continuous coaching in improving decision

\subsection{Data Analysis}


making and adaptation skills in the workplace and career (Babarović and Šverko, 2016).

\section{Conclusion}

The concentration of the solution greatly affected by the color density. The higher the solution density, the darker the color. In making color variations in batik coloring, students could dilute the concentration of the solution with a ratio of $1: 1$. The technique developed is categorized as easy and simple so it encourages young people to experiment themselves. The simple techniques will benefit students especially students with special needs. However, for students with cognitive barriers and the combination of other obstacles, it is necessary to conduct the stages directly and teachers provide brief explanations.

\section{Acknowledgements}

We would like to thank Universitas Pendidikan Indonesia for supporting this study.

Table 3 Pretest-Posttest 2 schools

\begin{tabular}{|c|c|c|c|c|c|c|}
\hline \multirow[b]{2}{*}{$\begin{array}{c}\text { Question } \\
\end{array}$} & \multicolumn{3}{|c|}{ Vocational High Schools (SMK) } & \multicolumn{3}{|c|}{ Senior High School (SMU) } \\
\hline & Pre-test & Post-test & Gain & Pre-test & Post-test & Gain \\
\hline $\begin{array}{l}\text { Is it necessary to mix two or more different substances to produce a batik dye } \\
\text { solution? }\end{array}$ & 80.00 & 100 & 20.00 & 80.00 & 100 & 20.00 \\
\hline $\begin{array}{l}\text { A solution is a mixture that is homogeneous because of its same composition and } \\
\text { properties and contains two or more substances whose proportions may be vary }\end{array}$ & 80.00 & 87.50 & 2.50 & 80.00 & 100 & 20.00 \\
\hline $\begin{array}{l}\text { The solvent is the component with the largest quantity, or it determines the form of } \\
\text { the solution material }\end{array}$ & 60.00 & 75.00 & 15.00 & 60.00 & 100 & 40.00 \\
\hline Limestone in the experiment is a solvent & 60.00 & 75.00 & 15.00 & 60.00 & 80.00 & 20.00 \\
\hline Turmeric is a solute & 100 & 87.50 & -2.50 & 100 & 100 & 0 \\
\hline Concentrated solutions have a relatively high quantity of solute & 80.00 & 75.00 & 5.00 & 80.00 & 80.00 & 0 \\
\hline Dilute solutions only have a low/small quantity of solute & 80.00 & 100 & 20.00 & 80.00 & 60.00 & -20.00 \\
\hline $\begin{array}{l}\text { Making a dilute solution and form a lighter color, it is done by taking some of the } \\
\text { dark color composition by adding a liquid amount of concentrated liquid. For } \\
\text { example, take } 1 / 2 \text { part of concentrated liquid, and add } 1 / 2 \text { the liquid of the same } \\
\text { size. }\end{array}$ & 80.00 & 87.50 & 2.50 & 80.00 & 80.00 & 0 \\
\hline Solution density is the amount of solute in each unit of solution or solvent. & 80.00 & 100 & 20.00 & 80.00 & 100 & 20.00 \\
\hline $\begin{array}{l}\text { At coarse limestone particle sizes, the concentration of the solution remains } \\
\text { unchanged. }\end{array}$ & 80.00 & 80.00 & 0 & 80.00 & 60.00 & -20.00 \\
\hline At the particle size of fine limestone, the concentration of the solution changes. & 80.00 & 87.50 & 7.50 & 80.00 & 100 & 20.00 \\
\hline $\begin{array}{l}\text { The concentration of turmeric powder remains the same from the start to the end of } \\
\text { the coloring process. }\end{array}$ & 40.00 & 87.50 & 47.50 & 40.00 & 60.00 & 20.00 \\
\hline The cloth dips in turmeric will change the color & 100 & 100 & 0 & 100 & 100 & 0 \\
\hline A cloth dips in clear limestone liquid does not change color & 100 & 87.50 & -2.50 & 100 & 60.00 & -40.00 \\
\hline $\begin{array}{l}\text { Turmeric which is only mixed in mineral liquid, the color remains yellow but can } \\
\text { fade or disappear }\end{array}$ & 100 & 100 & 0 & 100 & 60.00 & -40.00 \\
\hline $\begin{array}{l}\text { Turmeric mixed with a solution of whiting would bind the color and make the } \\
\text { fabric color lasts }\end{array}$ & 100 & 100 & 0 & 100 & 80.00 & -20.00 \\
\hline It could be concluded that the limestone solution is a color binder & 100 & 100 & 0 & 100 & 100 & 0 \\
\hline
\end{tabular}

\section{References}

Al-Azawei, A., Serenelli, F., and Lundqvist, K. (2016). Universal design for learning (UDL): A content analysis of peer reviewed journals from 2012 to 2015. Journal of the Scholarship of Teaching and Learning, 16(3), 39-56.

Amalia, R., and Akhtamimi, I. (2016). Studi pengaruh jenis dan konsentrasi zat fiksasi terhadap kualitas warna kain batik dengan pewarna alam limbah kulit buah rambutan (nephelium lappaceum). Majalah Ilmiah Dinamika Kerajinan dan Batik, 33(2), 85-92.

Ambarwati, W., and Budiningsih, C. A. (2018). The Effectiveness of video and random cars in the skills of experience-based story composition among the elementary school students. Jurnal Prima Edukasia, 6(2), 177-188.
Andansari, D., and Nadir, M. (2017). Eksplorasi Pewarnaan Beberapa Jenis Kain Menggunakan Pewarna Alami Jolawe Dan Secang Dengan Fiksasi Tawas, Baking Soda Dan Jeruk Nipis. Jurnal Kreatif: Desain Produk Industri Dan Arsitektur, 4(2), 9-9.

Babarović, T., and Šverko, I. (2016). Profesionalni razvoj u adolescenciji: konstrukcija karijere, poteškoće u donošenju profesionalnih odluka i profesionalna adaptabilnost učenika srednjih škola u hrvatskoj. Applied Psychology, 9(4), 429-448.

Budiningsih, C. A. (2011). Karakteristik siswa sebagai pijakan dalam penelitian dan metode pembelajaran. Jurnal Cakrawala Pendidikan, 1(1), 160-173.

Cahyono, E., Jonas, J. F., Lalenoh, B. A., and Kota, N. (2019). Karakterisasi Kalsium Karbonat (CaCO3) Dari Cangkang Landak Laut (Diadema setosum). Jurnal FishtecH, 8(1), 28-34. 
Dewy, S. S., and Novrita, S. Z. Pengaruh perbedaan larutan celup (vlot) terhadap hasil pencelupan zat warna alam ekstrak bawang dayak (eleutherine palmifolia (1.) merr.) pada bahan sutera dengan mordan tawas. Gorga: Jurnal Seni Rupa, 8(1), 248-254.

Ds, B. W., and Alvin, M. A. (2019). Teknik pewarnaan alam eco print daun ubi dengan penggunaan fiksator kapur, tawas dan tunjung. Jurnal Litbang Kota Pekalongan, $17,1-5$.

Prahesty, I. D., and Mulyana, O. P. (2013). Perbedaan kematangan karir siswa ditinjau dari jenis sekolah. Character, 2(1), 1-7.

Hakiim, A., Sari, D. A., and Efelina, V. (2019). Pengembangan Potensi Indigofera dengan Proses Kombinasi Fermentasi Aerob-anaerob sebagai Zat Warna Alami Batik. Journal of Chemical Process Engineering, 3(2), 1-7.

Handayani, W., Kristijanto, A. I., and Hunga, A. I. R. (2018). Behind the eco-friendliness of "batik warna alam": Discovering the motives behind the production of batik in Jarum village, Klaten. Wacana, 19(1), 235256.

Kartikasari, E., and Susiati, Y. T. (2016). Pengaruh fiksator pada ekstrak daun mangga dalam pewarnaan tekstil batik ditinjau dari ketahanan luntur warna terhadap keringat. SCIENCE TECH: Jurnal Ilmiah Ilmu Pengetahuan dan Teknologi, 2(1), 136-143.

Mayusoh, C. (2015). The art of designing, fabric pattern by tie-dyeing with natural dyes. Procedia-Social and Behavioral Sciences, 197, 1472-1480.

Oktiani, R., Ragadhita, R., Nandiyanto, A. B. D., Sukmafitri, A., Shintabella, R., and Widiaty, I. (2019). Existence of alum on the effectiveness of extracted miana leaves on batik coloring. Journal of Engineering Science and Technology, 14(3), 1662-1671.

Oktiani, R., Ragadhita, R., Nandiyanto, A. B. D., and Widiaty, I. (2020). Effect of solvents and fixation agents on colouring batik by guava leaves extract. Journal of Engineering Science and Technology, 15(4), 2301-2308.

Mujiono, M., Degeng, I. N. S., and Praherdhiono, H. (2018). Pengembangan pembelajaran sistem blended berbasis universal design for learning untuk kelas inklusif. Jurnal Pendidikan: Teori, Penelitian, dan Pengembangan, 3(6), 758-763.

Mumpuniarti, R. S., and Cahyaningrum, E. S. (2011). Kebutuhan belajar siswa lamban belajar (slow learner) di kelas awal sekolah dasar daerah istimewa yogyakarta. artikel penelitian. Pendidikan Luar Biasa Fakultas Ilmu Pendidikan Universitas Negeri Yogyakarta, 1-15.

Munisih, S., Hartati, H. C., and Amroni, M. (2010). Perbedaan sifat karakteristik fisik granul effervescent ekstrak kunyit (curcuma damestica val.) asam (tamarindus indica 1.) dengan bahanpengisi dekstrosa, sukrosa, dekstrosa-sukrosa (50: 50). Media Farmasi Indonesia, 5(1).
Moriña, A. (2017). Inclusive education in higher education: challenges and opportunities. European Journal of Special Needs Education, 32(1), 3-17.

Parsons, J., and Taylor, L. (2011). Improving student engagement. Current Issues in Education, 14(1), 132.

Pujilestari, T. (2014). Pengaruh ekstraksi zat warna alam dan fiksasi terhadap ketahanan luntur warna pada kain batik katun. Dinamika Kerajinan dan Batik, 31(1), 31-40.

Pujilestari, T. (2016). Sumber dan pemanfaatan zat warna alam untuk keperluan industri. Dinamika Kerajinan dan Batik: Majalah Ilmiah, 32(2), 93-106.

Purnaningtyas, D. N., and Sriyanto, S. (2014). Desain eksperimen pewarna alam batik propagul mangrove dengan tingkat ketahanan luntur warna yang baik dengan bantuan zat fiksatif tawas. Industrial Engineering Online Journal, 3(2). 1-9.

Radhakrishnan, S. (2014). Application of biotechnology in the processing of textile fabrics. In Roadmap to Sustainable Textiles and Clothing, Springer, Singapore, 277-325.

Sdiri, A., Higashi, T., Jamoussi, F., and Bouaziz, S. (2012). Effects of impurities on the removal of heavy metals by natural limestones in aqueous systems. Journal of Environmental management, 93(1), 245-253.

Setyawati, H., Darmokoesoemo, H., Ningtyas, A. T. A., Kadmi, Y., Elmsellem, H., and Kusuma, H. S. (2017). Effect of metal ion Fe (III) on the performance of chlorophyll as photosensitizers on dye sensitized solar cell. Results in physics, 7, 2907-2918.

Suheryanto, D., and Haryanto, T. (2016). Pengaruh konsentrasi tawas terhadap ketuaan dan ketahanan luntur warna pada pencelupan kain sutera dengan zat warna gambir. Dinamika Kerajinan dan Batik: Majalah Ilmiah, 25(1), 9-16.

Suparwati, T. (2017). Karakteristik larutan kimia di dalam air dengan menggunakan sistem persamaan linear. Prosiding Seminar Nasional Metode Kuantitatif , 978, 389-397.

Widiaty, I., Riza, L. S., Abdullah, A. G., and Mubaroq, S. R. (2020). Multiplatform application technology-based heutagogy on learning batik: A curriculum development framework. Indonesian Journal of Science and Technology, 5(1), 45-61. 